\title{
Sensitivity of Cladosporium caryigenum to Propiconazole and Fenbuconazole
}

Katherine L. Reynolds, Department of Plant Pathology, University of Georgia, Athens 30602-7274; Timothy B. Brenneman, Department of Plant Pathology, University of Georgia, Coastal Plain Experiment Station, Tifton 31793; and Paul F. Bertrand, Department of Plant Pathology, University of Georgia, Rural Development Center, Tifton 31793

\begin{abstract}
Reynolds, K. L., Brenneman, T. B., and Bertrand, P. F. 1997. Sensitivity of Cladosporium caryigenum to propiconazole and fenbuconazole. Plant Dis. 81:163-166.

Monoconidial isolates of the pecan scab fungus, Cladosporium caryigenum, were obtained in 1993 and 1994 from one pecan orchard each in Jeff Davis and Troup counties in Georgia, counties with no previous history of exposure to demethylation-inhibiting (DMI) fungicides. Isolates were grown on potato dextrose agar (PDA) amended with propiconazole or fenbuconazole at 0 , $0.0001,0.0005,0.001,0.005,0.01,0.05,0.1,0.5,1.0$, or $5.0 \mu \mathrm{g} \mathrm{ml}^{-1}$. After 4 to 5 weeks at $25^{\circ} \mathrm{C}$, the diameter of each colony was measured. Relative growth was expressed as the colony diameter for each fungicide concentration as a percentage of the diameter on unamended PDA. $\mathrm{ED}_{50}$ values for both fungicides in all years and locations were lognormally distributed. Mean $\mathrm{ED}_{50}$ values ranged from 0.19 to $0.30 \mu \mathrm{g} \mathrm{ml}^{-1}$ for fenbuconazole and 0.12 to $0.17 \mu \mathrm{g} \mathrm{ml}^{-1}$ for propiconazole. There were highly significant positive correlations between sensitivity to propiconazole and sensitivity to fenbuconazole at all locations and years, indicating significant potential for development of cross-resistance to these compounds. A discriminatory concentration of $0.2 \mu \mathrm{g} \mathrm{ml}^{-1}$ propiconazole was selected for further monitoring of DMI sensitivity. With this discriminatory concentration, a sample size of 50 isolates was estimated to be sufficient to detect a difference of $8.3 \%$ in mean relative growth between two populations.
\end{abstract}

Additional keywords: fungicide resistance, fungicide sensitivity, sterol demethylation inhibitors, triazole

Pecan scab, caused by Cladosporium caryigenum (Ellis \& Langl.) Gottwald, is the major disease of, and the target for most fungicide applications on, pecan (Carya illinoensis (F. A. Wagenheim) K. Koch). Control of pecan scab generally requires five to nine fungicide applications each year. Although fentin hydroxide (Super Tin 80WP; Griffin Corporation, Valdosta, GA) has been the most widely used fungicide for scab control, propiconazole (Orbit 3.6E; Ciba-Geigy Corp., Greensboro, NC) is also very effective against scab, particularly during the foliar phase in the early part of the season, and has been available for use on pecans since 1988 (1). Fenbuconazole (Enable 2F; Rohm \& Haas Co., Philadelphia, PA) was introduced on the market in 1995 and represents the latest addition to the inventory of products available for control of pecan scab.

Both fenbuconazole and propiconazole belong to the triazole class of fungicides known as sterol demethylation inhibitors (DMIs) that share a similar site-specific mode of action. Shifts in DMI-sensitivity

Corresponding author: Katherine L. Reynolds E-mail: reynolds@uga.cc.uga.edu

Accepted for publication 17 October 1996.

Publication no. D-1996-1121-05R

(C) 1997 The American Phytopathological Society of pathogen populations have been detected without any significant loss of control $(22,25)$. However, intensive use of DMI fungicides has led to disease control failures associated with significant shifts toward reduced fungicide sensitivity in the pathogen $(3,4,8,10-12,18,19)$. Changes in DMI sensitivity occurred in an incremental fashion and monitoring programs have been proposed to detect subtle changes in pathogen sensitivity before control is compromised $(5,6)$. Implementation of antiresistance strategies can prevent or delay development of high levels of resistance in pathogen populations $(2,13,23,24)$.

A dramatic increase in the use of DMIs for control of pecan scab in the southeastern U.S. could result in increased selection pressure, leading to an increased risk of resistance in populations of $C$. caryigenum. As a precaution, steps have been taken to incorporate antiresistance strategies in scab control programs. In the case of propiconazole on pecans, restrictions on the label limit the total amount of the compound applied per season. Recommended use of DMI fungicides for scab control in Georgia includes application of DMIs in blocks of two to four sprays, applied prior to pollination, followed by postpollination applications of multisite fungicides that are chemically unrelated to the DMIs (such as fentin hydroxide) (9). Implementation of a monitoring program would enable assessment of the effectiveness of these strate- gies and detection of any significant change in pathogen sensitivity that might signal impending loss of disease control.

This study was the first phase in the development of a program to monitor fungicide sensitivity in the pecan scab pathogen and assess the effectiveness of resistance management strategies in pecans. The objectives were to (i) characterize the distributions of sensitivity to propiconazole and fenbuconazole in populations of $C$. caryigenum previously unexposed to DMI fungicides, (ii) assess the potential for crossresistance to propiconazole and fenbuconazole in $C$. caryigenum, and (iii) identify a discriminatory concentration of fungicide and appropriate sample sizes for a monitoring program to detect significant shifts in DMI-sensitivity in exposed populations of $C$. caryigenum. Portions of this work have been reported previously (17).

\section{MATERIALS AND METHODS}

Sampling locations and fungal isolations. Samples of pecan leaves with actively sporulating scab lesions were collected from orchards with no history of exposure to DMI fungicides, in the spring of 1993 and 1994. These sites were far from any commercial pecan orchards where DMI fungicides have been used. On 7 July 1993, leaves were collected from an unmanaged pecan orchard in Troup County, GA, that consisted predominantly of the cv. Stuart. In 1994, leaves were collected on 24 May from a second site in Jeff Davis County, GA, where the predominant cultivar was Schley, and on 30 May from the same unmanaged orchard in Troup County that was sampled the previous year.

One scab lesion was cut from each sampled leaf with a cork borer and gently rubbed (sporulating side down) on the surface of $4 \%$ water agar amended with $50 \mu \mathrm{g}$ $\mathrm{ml}^{-1}$ each of chloramphenicol, streptomycin sulfate, and tetracycline to inhibit bacterial growth. The plates were placed in plastic bags and incubated in the dark at $25^{\circ} \mathrm{C}$ for 18 to $24 \mathrm{~h}$. Single, germinated conidia were transferred to plates of potato dextrose agar (PDA) amended with the same concentrations of antibiotics and incubated in the dark at $25^{\circ} \mathrm{C}$ for 6 weeks.

Fungicide sensitivity assay. The sensitivity of each isolate to fenbuconazole and propiconazole was determined by a modification of the mycelial growth assay recommended for DMI fungicides (20). In 1993, 35 monoconidial isolates from the 
orchard in Troup County (TR isolates) were assayed for fungicide sensitivity. In 1994, 98 monoconidial TR isolates and 96 monoconidial isolates from the orchard in Jeff Davis County (JD isolates) were assayed. Each 6-week-old fungal colony was cut from the agar and homogenized in $1 \mathrm{ml}$ of sterile water to provide a uniform suspension of mycelium. Twenty microliters of the mycelial suspension was transferred to each of two 4-mm-diameter wells cut in plates of PDA amended with fenbuconazole or propiconazole at a concentration of 0, 0.0001, 0.0005, 0.001, 0.005, 0.01, 0.05, $0.1,0.5,1.0$, or $5.0 \mu \mathrm{g} \mathrm{ml} \mathrm{m}^{-1}$. Fungicide concentrations were prepared with technical grade fungicide dissolved in acetone. Fungicide solutions were added to autoclaved PDA cooled to $55^{\circ} \mathrm{C}$, such that the final concentration of acetone was $0.1 \%$ (vol/vol) in all treatments, including the unamended control. After 4 weeks of incubation in the dark at $25^{\circ} \mathrm{C}$, the diameter of each fungal colony was measured, adjusted by subtracting the diameter of the well, and the mean adjusted colony diameter was determined for each isolate and fungicide concentration. Relative growth for each isolate was expressed as the mean adjusted colony diameter on each fungicide concentration as a percentage of the mean adjusted diameter on unamended PDA.

Statistical analyses. Linear regression of relative growth on the $\log _{10}$-transformed fungicide concentration was used to estimate $\mathrm{ED}_{50}$ values for each isolate, $t$ tests were performed to compare mean $\log _{10^{-}}$ transformed $\mathrm{ED}_{50}$ values between years and locations, and simple linear correlation

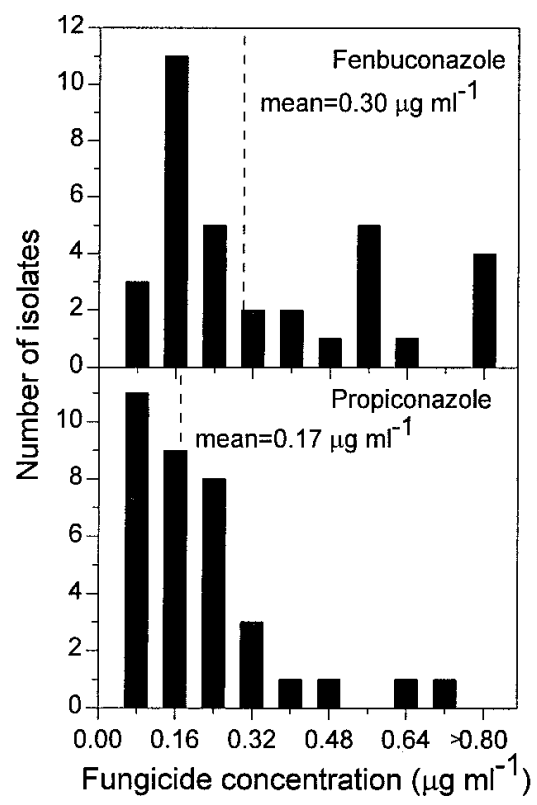

Fig. 1. Frequency distribution of $\mathrm{ED}_{50}$ values for isolates of Cladosporium caryigenum for fenbuconazole (top) and propiconazole (bottom). Thirty-five isolates were obtained in 1993 from an orchard in Troup County, GA, that had never been exposed to demethylation-inhibiting fungicides. coefficients were calculated to determine the relationship between sensitivity to propiconazole and sensitivity to fenbuconazole and to evaluate the potential for the development of cross-resistance between compounds. A resistance factor was calculated for each sample as the ratio of the $\mathrm{ED}_{50}$ value of the least sensitive isolate (maximum $\mathrm{ED}_{50}$ value) to the mean $\mathrm{ED}_{50}$ value for that sample. Discriminatory concentrations of each fungicide were selected based on the mean $\mathrm{ED}_{50}$ values of the baseline populations. Sample sizes required for monitoring sensitivity shifts with a single discriminatory concentration were estimated based on the variation in relative growth on the fungicide concentrations close to the discriminatory concentration (e.g., 0.1 and $0.5 \mu \mathrm{g} \mathrm{m}{ }^{-1}$ ). A procedure for estimation of sample sizes in comparative experiments was used to determine approximate sample sizes (21).

\section{RESULTS}

Sensitivity distributions. The frequency distribution of $\mathrm{ED}_{50}$ values of isolates was log-normal for all sites, years, and fungicides tested. In 1993, the mean $\mathrm{ED}_{50}$ values for the TR isolates were 0.30 and $0.17 \mu \mathrm{g} \mathrm{ml}^{-1}$ for fenbuconazole and propiconazole, respectively (Fig. 1). In 1994 , the mean $\mathrm{ED}_{50}$ value for fenbuconazole for the TR isolates was $0.25 \mu \mathrm{g} \mathrm{ml}^{-1}$, compared with $0.19 \mu \mathrm{g} \mathrm{ml}{ }^{-1}$ for the JD isolates (Fig. 2). A similar difference in mean $\mathrm{ED}_{50}$ value for propiconazole also was observed between the two sites. The mean $\mathrm{ED}_{50}$ value for propiconazole for the TR isolates was $0.17 \mu \mathrm{g} \mathrm{ml}^{-1}$, compared with $0.12 \mu \mathrm{g} \mathrm{ml}^{-1}$ for the JD isolates (Fig. 3 ). For both fungicides, the difference in mean $\mathrm{ED}_{50}$ value between locations was biologically small but statistically significant due to the relatively large sample sizes. However, the variation in sensitivity also differed between locations. For both fungicides, the variance and range of $\mathrm{ED}_{50}$ values were consistently larger for the JD isolates than the TR isolates (Table 1). This difference also was reflected in the calculated resistance factors for the two locations in 1994. The resistance factors for both fungicides were greater for the TR isolates than the JD isolates (Table 1). And for both sampling locations, the difference between $\mathrm{ED}_{50}$ values of the least sensitive isolates and the mean was considerably greater for fenbuconazole than for propiconazole. This difference was reflected in the higher resistance factors for fenbuconazole than propiconazole at both locations (Table 1).

There were significant and positive correlations between the sensitivities to propiconazole and fenbuconazole within our baseline samples (Table 2). The highly significant correlation coefficients ranged from 0.63 to 0.83 for the different years and locations. The relationship between sensitivity to the two fungicides for pooled data from all years and locations is shown in Figure 4.

Discriminatory concentrations and required sample sizes. Discriminatory concentrations of $0.2 \mu \mathrm{g} \mathrm{ml}^{-1}$ and $0.3 \mu \mathrm{g}$ $\mathrm{ml}^{-1}$ were chosen for propiconazole and fenbuconazole, respectively, for use in further sensitivity monitoring studies. These concentrations represent values just slightly higher than the mean $\mathrm{ED}_{50}$ value of the unexposed populations (20). Estimated sample sizes required to detect differences in mean relative growth on the discriminatory concentrations are shown in Figure

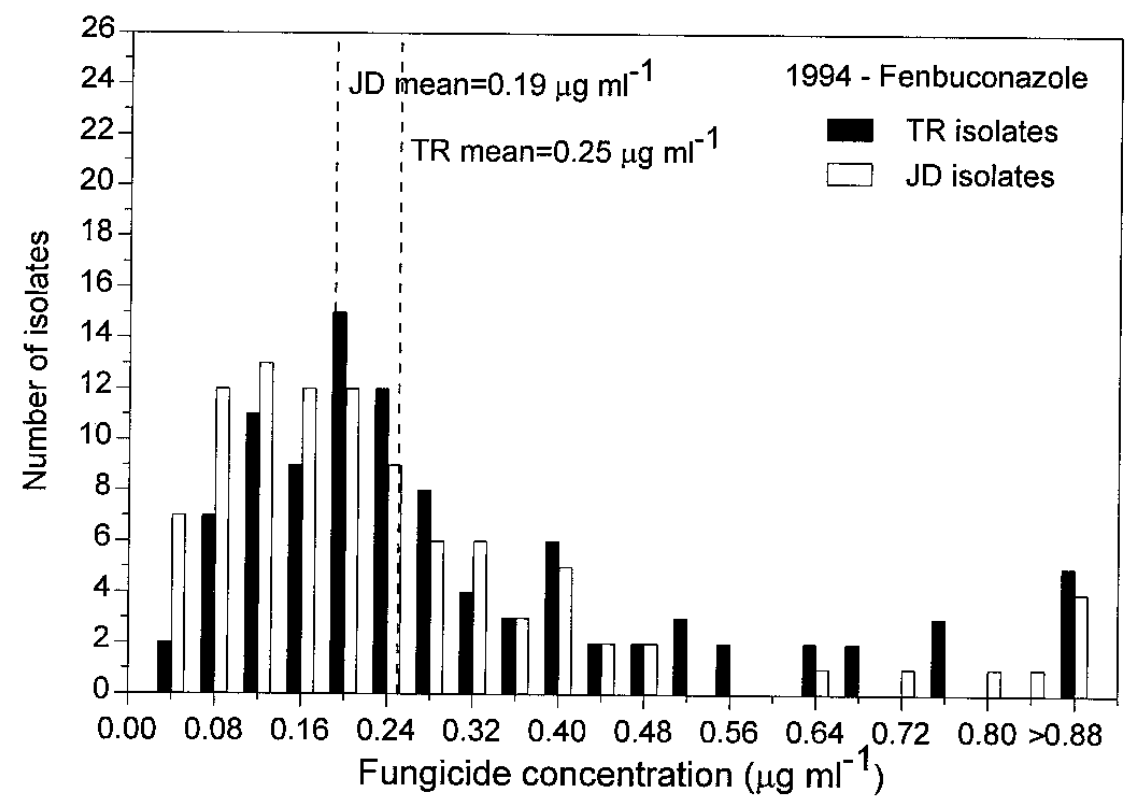

Fig. 2. Frequency distribution of $\mathrm{ED}_{50}$ values for isolates of Cladosporium caryigenum to fenbuconazole. Ninety-eight isolates were obtained from an orchard in Troup County (TR isolates) and 96 from Jeff Davis County (JD isolates) in Georgia during 1994. 
5. A sample size of 50 isolates was chosen for monitoring DMI sensitivity in populations of $C$. caryigenum. This sample size was estimated to be sufficient to detect a difference in mean relative growth of $9.1 \%$ on $0.3 \mu \mathrm{g} \mathrm{ml}^{-1}$ fenbuconazole and $8.3 \%$ on $0.2 \mu \mathrm{g} \mathrm{ml}^{-1}$ propiconazole.

\section{DISCUSSION}

Characterization of the baseline sensitivity distribution is the first step in establishing a fungicide resistance monitoring program to detect changes in sensitivity, assess the impact of fungicide use patterns, and evaluate the effectiveness of resistance management programs. This study represents the first report of sensitivity of unexposed populations of the pecan scab fungus, $C$. caryigenum, to the DMI fungicides propiconazole and fenbuconazole. Both fungicides are recommended for pecan scab control (9) and are valued components of scab management programs due to their systemic and eradicant activity $(15,16)$.

Lognormal distributions of sensitivity to DMI fungicides are consistent with reports of DMI sensitivity distributions in other fungi $(7,20)$. Although statistically significant differences were observed in mean $\mathrm{ED}_{50}$ values between the two sampling locations, the differences were very small and probably not biologically meaningful. The relative differences between these unexposed locations were negligible relative to the shifts in sensitivity required to result in loss of control. The resistance factors reported here for unexposed isolates of $C$. caryigenum are similar in magnitude to those reported for DMI baseline populations of Venturia inaequalis $(14,20)$. Within each sample of isolates tested, the resistance factor was consistently greater for fenbuconazole than propiconazole (Table 1). The difference in resistance factors reflects greater variation in sensitivity to fenbuconazole within baseline populations of $C$. caryigenum. The resistance factor provides an indication of the potential for development of resistance in a population. The higher the resistance factor, the greater the difference in sensitivity between the least sensitive individuals in a population relative to the mean sensitivity of the entire population and, therefore, the greater the potential for development of resistance.

There were significant positive correlations between the sensitivities to propiconazole and fenbuconazole within our baseline samples. The high degree of positive correlation indicates that there is a significant potential for cross-resistance between these compounds. This is consistent with similar reports of positively correlated sensitivities to DMI fungicides in other fungi $(11,14,25)$. The potential for cross-resistance between DMI compounds used for pecan disease control emphasizes the need for effective alternative fungicide partners for the DMIs and implementation of appropriate resistance management pro- grams to prevent the buildup of DMI resistance in populations of $C$. caryigenum. Although sensitivities to these two DMI fungicides were highly correlated, isolates were not in general equally sensitive to both compounds. The mechanism of action of the DMI fungicides is identical, but intrinsic activity of the individual compounds is not. In general, isolates were more sensitive to propiconazole than to the same concentration of fenbuconazole. This difference in activity may reflect differential uptake by the fungus or some other consequence of the unique biochemical properties of the individual compounds. Differences in baseline sensitivities among DMIs have been noted for Venturia inaequalis (14). Mean $\mathrm{ED}_{50}$ values for baseline isolates of $V$. inaequalis ranged from 0.008 $\mu \mathrm{g} \mathrm{ml}^{-1}$ for flusilazole to $0.07 \mu \mathrm{g}$ $\mathrm{ml}^{-1}$ for myclobutanil.

For DMI fungicides, establishment of a sensitivity monitoring program could be effective for early detection of reduced sensitivity in populations of $C$. caryigenum before appreciable loss of disease control is observed (5). A mycelial growth assay with a single discriminatory concentration provides a relatively easy and efficient means of monitoring changes in fungicide sensitivity (20). Because the sensitivities to propiconazole and fenbuconazole were highly correlated, sensitivity to these fungicides could be monitored adequately with only a single compound. The choice of fungicide and discriminatory concentration depends in part on the objectives of the monitoring program. Due to the greater

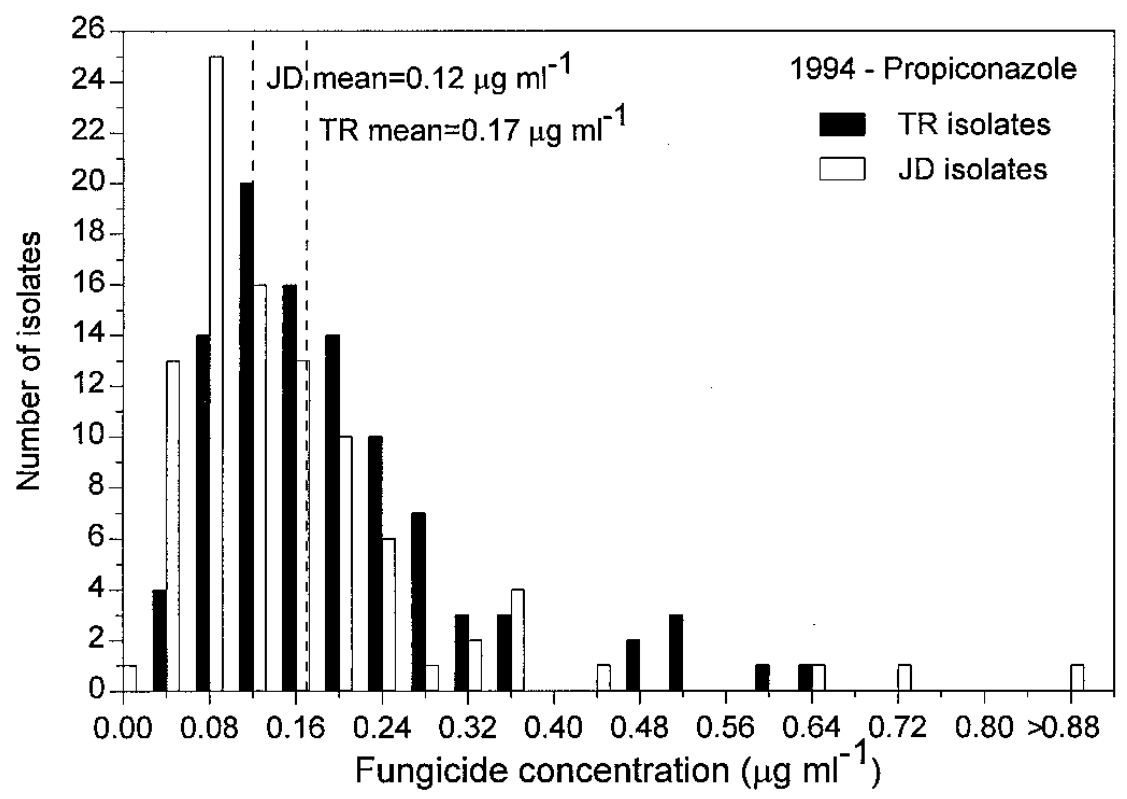

Fig. 3. Frequency distribution of $\mathrm{ED}_{50}$ values for isolates of Cladosporium caryigenum to propiconazole. Ninety-eight isolates were obtained from an orchard in Troup County (TR isolates) and 96 from Jeff Davis County (JD isolates) in Georgia during 1994.

Table 1. Characteristics of the frequency distributions of $\mathrm{ED}_{50}$ values for propiconazole and fenbuconazole of isolates of Cladosporium caryigenum collected in 1994 from two orchards in Georgia with no history of exposure to demethylation-inhibiting fungicides

\begin{tabular}{llccr}
\hline & & \multicolumn{2}{c}{ ED $_{\mathbf{5 0}}$ value $\left(\boldsymbol{\mu g ~ \mathbf { ~ m l } ^ { \mathbf { - 1 } } )}\right.$} & \\
\cline { 3 - 4 } Fungicide & \multicolumn{1}{c}{ Location } & Range & Mean & Resistance factor $^{\mathbf{a}}$ \\
\hline Propiconazole & Troup Co. & 0.030 to 0.647 & 0.165 & 4 \\
& Jeff Davis Co. & 0.013 to 1.102 & 0.121 & 9 \\
Fenbuconazole & Troup Co. & 0.044 to 2.340 & 0.248 & 9 \\
& Jeff Davis Co. & 0.028 to 2.415 & 0.191 & 13 \\
\hline
\end{tabular}

a Ratio of the maximum $\mathrm{ED}_{50}$ value to the mean.

Table 2. Correlation between $\log _{10}$-transformed $\mathrm{ED}_{50}$ values for propiconazole and fenbuconazole for monoconidial isolates of Cladosporium caryigenum collected in 1993 and 1994 from pecan orchards with no history of exposure to demethylation-inhibiting fungicides

\begin{tabular}{lccc}
\hline Location & Year & Number of isolates & Correlation coefficient $(\mathbf{r})^{\mathbf{a}}$ \\
\hline Troup Co. & 1993 & 35 & $0.83^{*}$ \\
Troup Co. & 1994 & 98 & $0.76^{*}$ \\
Jeff Davis Co. & 1994 & 96 & $0.63^{*}$ \\
\hline
\end{tabular}

a Correlation coefficients followed by * are significantly different from zero $(P=0.0001)$. 


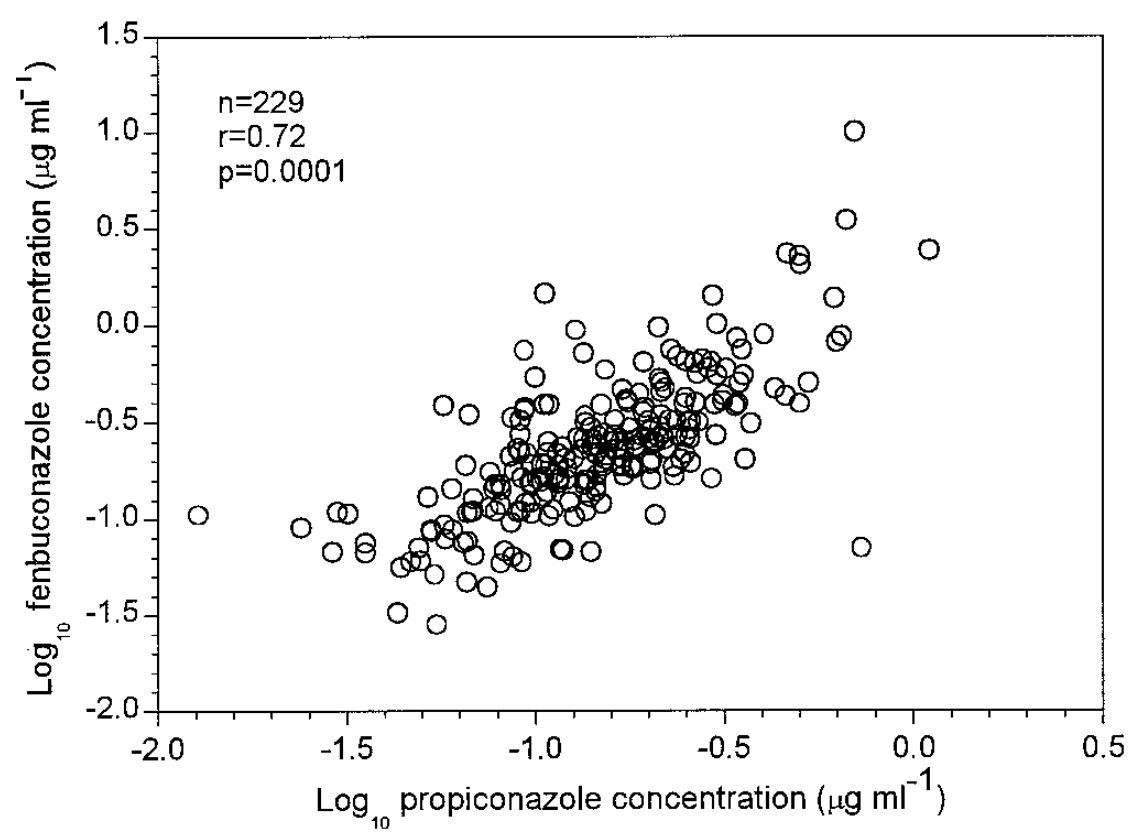

Fig. 4. Correlation between $\log _{10}$-transformed $\mathrm{ED}_{50}$ values for isolates of Cladosporium caryigenum to fenbuconazole and propiconazole. A total of 229 isolates was collected in 1993 and 1994 from two locations in Georgia with no previous history of exposure to demethylation-inhibiting fungicides.

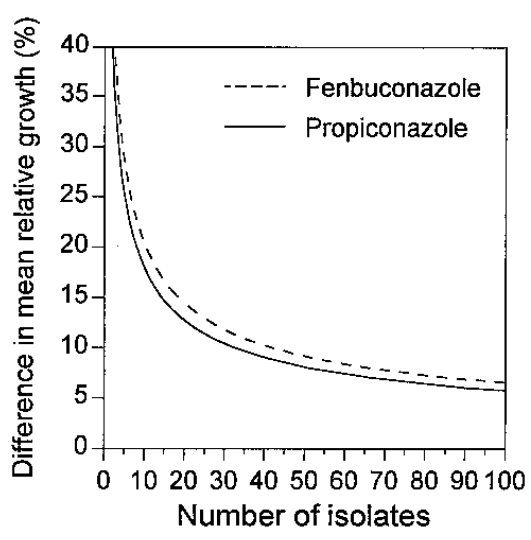

Fig. 5. Estimated sample sizes required to detect a difference in the mean relative growth (\%) between two populations of Cladosporium caryigenum, based on mycelial growth at a single discriminatory concentration of fungicide.

variation in sensitivity to fenbuconazole within baseline populations of $C$. caryigenum and the slightly lower intrinsic activity, compared with propiconazole, one might expect that repeated exposure to DMIs may result in selection of fenbuconazole resistance sooner than propiconazole resistance. Therefore, if the goal of sensitivity monitoring is to detect the presence of highly insensitive individuals in the population, then a relatively high concentration of fenbuconazole close to the mean $\mathrm{ED}_{95}$ for the baseline population would be an appropriate choice for monitoring purposes. However, if the goal of the monitoring program is to detect small changes in the mean sensitivity of a pathogen population, then a sensitivity assay based on a discriminatory concentration of the baseline population (e.g., $0.2 \mu \mathrm{g} \mathrm{ml}^{-1}$ ) would be a better choice than fenbuconazole because slightly smaller differences in mean sensitivity could be detected for a given sample size.

\section{ACKNOWLEDGMENTS}

This research was supported with funds provided by Ciba-Geigy Corporation, Rohm and Haas Company, and the Southeastern Pecan Growers Association. We thank D. Denney, C. Gray, and L. Russell for technical assistance.

\section{LITERATURE CITED}

1. Bertrand, P. F., and Hadden, J. 1992. Fungicide use on Georgia pecans. Proc. Southeast. Pecan Grow. Assoc. 85:45-53.

2. Bolton, N. J. E., and Smith, J. M. 1988. Strategies to combat fungicide resistance in barley powdery mildew. Proc. Brighton Crop Prot. Conf. Pests Dis. 1:367-372.

3. Braun, P. G. 1994. Development and decline of a population of Venturia inaequalis resistant to sterol-inhibiting fungicides. Norw. J. Agric. Sci. 17:173-184.

4. Braun, P. G., and McRae, K. B. 1992. Composition of a population of Venturia inaequalis resistant to myclobutanil. Can. J. Plant

5. Brent, K. 1992. Monitoring fungicide resistance: purposes, procedures, and progress. Pages 1-18 in: Resistance '91: Achievements and Developments in Combating Pesticide Resistance. E. Denholm, A. L. Debonshire, and D. W. Hollomon, eds. Elsevier Applied Science, London.

6. Brent, K. J. 1988. Monitoring for fungicide resistance. Pages 9-11 in: Fungicide Resistance in North America. C. J. Delp, ed. American Phytopathological Society, St. Paul, MN.

7. Carisse, O., and Pelletier, J. R. 1994. Sensitivity distribution of Venturia inaequalis to fenarimol in Quebec apple orchards. Phytopropiconazole close to the mean $\mathrm{ED}_{50}$ for Pathol. 14:215-220. protection 75:35-43.
8. De Waard, M. A., Kipp, E. M. C., Horn, N. M., and Van Nistelrooy, J. G. M. 1986. Variation in sensitivity to fungicides which inhibit ergosterol biosynthesis in wheat powdery mildew. Neth. J. Plant Pathol. 92:21-32.

9. Ellis, H. C., Bertrand, P., Crocker, T. F., and MacDonald, G. 1996. Georgia Pecan Pest Management Guide. University of Georgia College of Agriculture/USDA Bull. No. 841.

10. Fiaccadori, R., Gielink, A. J., and Dekker, J. 1987. Sensitivity to inhibitors of sterol biosynthesis in isolates of Venturia inaequalis from Italian and Dutch orchards. Neth. J. Plant Pathol. 93:285-287.

11. Golembiewski, R. C., Vargas, J. M., Jr., Jones, A. L., and Detweiler, A. R. 1995. Detection of demethylation inhibitor (DMI) resistance in Sclerotinia homoeocarpa populations. Plant Dis. 79:491-493.

12. Hildebrand, P. D., Lockhart, C. L., Newbery, R. J., and Ross, R. G. 1988. Resistance of Venturia inaequalis to bitertanol and other demethylation-inhibiting fungicides. Can. J. Plant Pathol. 10:311-316.

13. Hunter, T., Brent, K. J., and Carter, G. A. 1984. Effects of fungicide regimes on sensitivity and control of barley mildew. Proc. 1984 Br. Crop Prot. Conf. - Pests Dis. 2:471476.

14. Köller, W., Parker, D. M., and Reynolds, K. L. 1991. Baseline sensitivities of Venturia inaequalis to sterol demethylation inhibitors. Plant Dis. 75:726-728.

15. Latham, A. J. 1984. Performance of some sterol-inhibiting fungicides against pecan scab. Pecan South 11:6-10.

16. Latham, A. J., and Hammond, J. M. 1983. Control of Cladosporium caryigenum on pecan leaves and nut shucks with propiconazole (CGA-64250). Plant Dis. 67:1136-1139.

17. Reynolds, K. L., Brenneman, T. B., Bertrand, P. F., and Culbreath, A. K. 1995. Sensitivity of Cladosporium caryigenum to propiconazole and fenbuconazole. (Abstr.). Phytopathology 85:1149.

18. Schepers, H. T. A. M. 1983. Decreased sensitivity of Sphaerotheca fuliginea to fungicides which inhibit ergosterol biosynthesis. Neth. J. Plant Pathol. 89:185-187.

19. Sheridan, J. E., Grbavac, N., and Sheridan, M. H. 1985. Triadimenol insensitivity in Pyrenophora teres. Trans. Br. Mycol. Soc. 85:338341.

20. Smith, F. D., Parker, D. M., and Köller, W. 1991. Sensitivity distribution of Venturia inaequalis to the sterol demethylation inhibitor flusilazole: Baseline sensitivity and implications for resistance monitoring. Phytopathology 81:392-396.

21. Snedecor, G. W., and Cochran, W. G. 1982. Statistical Methods. 7th ed. Iowa State University Press. Ames.

22. Stanis, V. F., and Jones, A. L. 1985. Reduced sensitivity to sterol-inhibiting fungicides in field isolates of Venturia inaequalis. Phytopathology 75:1098-1101.

23. Staub, T. 1991. Fungicide resistance: practical experience with antiresistance strategies and the role of integrated use. Annu. Rev. Phytopathol. 29:421-442.

24. Stott, I. P. H., Noon, R. A., and Heaney, S. P. 1990. Flutriafol, ethirimol and thiabendazole seed treatment - an update on field performance and resistance monitoring. Proc. Brighton Crop Prot. Conf. Pests Dis. 3:1169-1174.

25. Thind, T. S., Clerjeau, M., and Olivier, J. M. 1986. First observations on resistance in Venturia inaequalis and Guignardia bidwellii to ergosterol-biosynthesis inhibitors in France. Proc. Br. Crop Prot. Conf. Pests Dis. 2:491498. 